\title{
Pengembangan RPP Berorientasi Pembelajaran Abad 21 dengan Model Contextual Teaching and Learning Berbasis Tri Kaya Parisudha
}

\author{
Ni Putu Candra Prastya Dewi ${ }^{*}$, I Made Ari Winangun ${ }^{2}$ \\ Sekolah Tinggi Agama Hindu Negeri Mpu Kuturan, Singaraja, Indonesia \\ *Corresponding author: pendidikan.dasar500@gmail.com
}

\begin{abstract}
The learning process, especially in elementary schools, has not applied innovative learning models so that the quality of the learning process is still low. Therefore, improvement efforts are needed so that the learning process runs optimally through a development research that aimed to: (i) develop a 2013 curriculum oriented lesson plan for the 21st century with a contextual and teaching learning (CTL) model based on Tri Kaya Parisudha; (ii) determine the validity of the development of the 2013 Curriculum RPP oriented to 21st century learning with a Contextual and Teaching Learning model based on Tri Kaya Parisudha. This research is the result of design and product development (Design and Development) using the ADDIE Model (Analysis, Design, Development, Implementation, Evaluation). The subjects in this study consisted of 2 experts, 6 students, and 8 elementary school teachers. The data analysis method used is quantitative descriptive analysis. Methods of data collection using a questionnaire. The results of this study indicate that:(i) 2013 Curriculum RPP oriented to 21st century learning with a Contextual and Teaching Learning (CTL) model based on Tri Kaya Parisudha; (ii)The results of the expert validity test and the responses of elementary school teachers and PGSD students showed a very good category, so that the development of the 2013 Curriculum RPP with the Tri Kaya Parisudha-based Contextual and Teaching Learning (CTL) model was feasible to be applied to the Elementary School Teacher Education study program.
\end{abstract}

Keywords: 21st century learning; contextual and teaching learning; tri kaya parisudha

\section{ABSTRAK}

Proses pembelajaran khususnya di sekolah dasar secara aplikatif belum menerapkan model pembelajaran inovatif sehingga kualitas proses pembelajaran masih rendah. Oleh karena itu, diperlukan upaya perbaikan agar proses pembelajaran berjalan dengan optimal melalui suatu penelitian pengembangan yang bertujuan untuk: (i) mengembangkan RPP Kurikulum 2013 berorientasi pembelajaran abad 21 dengan model contextual and teaching learning (CTL) berbasis Tri Kaya Parisudha; (ii) mengetahui validitas pengembangan RPP Kurikulum 2013 berorientasi pembelajaran abad 21 dengan model Contextual and Teaching Learning berbasis Tri Kaya Parisudha. Penelitian ini merupakan hasil pengembangan desain dan produk (Design and Development) dengan menggunakan Model ADDIE (Analysis, Design, Development, Implementation, Evaluation). Subjek pada penelitian ini terdiri dari 2 orang ahli, 6 orang mahasiswa, dan 8 orang guru sekolah dasar. Metode analisis data yang digunakan adalah analisis deskriptif kuantitatif. Metode pengumpulan data menggunakan kuesioner. Hasil penelitian ini menunjukkan bahwa: (i) RPP Kurikulum 2013 berorientasi pembelajaran abad 21 dengan model Contextual and Teaching Learning (CTL) berbasis Tri Kaya Parisudha. Hasil uji validitas ahli maupun respons guru SD dan mahasiswa PGSD menunjukkan kategori sangat baik, sehingga pengembangan RPP Kurikulum 2013 dengan model Contextual and Teaching Learning (CTL) berbasis Tri Kaya Parisudha layak untuk diterapkan pada program studi Pendidikan Guru Sekolah Dasar.

Kata Kunci: contextual and teaching learning; pembelajaran abad 21; tri kaya parisudha

\section{Pendahuluan}

Terdapat berbagai permasalahan pembelajaran di sekolah dasar, diantaranya belum dikembangkannya model pembelajaran inovatif, minat belajar siswa yang rendah, dan lain sebagainya. Permasalahan tersebut tentunya perlu dicarikan solusinya untuk memperbaiki kualitas pembelajaran di sekolah dasar. Oleh karena itu, program studi Pendidikan Guru 
Sekolah Dasar untuk mencetak calon guru SD yang berkualitas perlu mengembangkan model inovatif sehingga dapat mengatasi permasalahan pembelajaran di SD nantinya.

Salah satu hal yang perlu dipersiapkan oleh guru sebelum melaksanakan pembelajaran adalah Rencana Pelaksanaan Pembelajaran (RPP) yang perlu dipersiapkan dengan baik. RPP yang dibuat disesuaikan dengan surat edaran mendikbud nomor 14 tahun 2019 mengenai penyederhanaan RPP, yang semula 13 komponen menjadi 3 komponen. Dalam perancangan RPP tersebut perlu juga digunakan model pembelajaran inovatif. Salah satunya yaitu model Contextual and Teaching Learning. Model Contextual and Teaching Learning adalah konsep belajar yang dapat membantu guru mengaitkan antara materi yang diajarkannya dengan situasi dunia nyata siswa dan mendorong siswa membuat hubungan antara pengetahuan yang dimiliki dengan penerapannya dalam kehidupan mereka sebagai anggota keluarga dan masyarakat (Rusman, 2013). Adapun prinsip pembelajaran kontekstual yaitu saling ketergantungan, prinsip diferensiasi (menghargai keragaman), prinsip pengaturan diri (mengeluarkan seluruh potensinya. Dengan prinsip tersebut nantinya diharapkan dapat mendorong peserta didik untuk melaksanakan pembelajaran lebih bermakna.

Pembelajaran kontekstual akan lebih bermakna dan dapat menanamkan Pendidikan karakter dengan dikaitkan dnegan konsep kearifan lokal Bali yaitu Tri Kaya Parisudha. Tri Kaya Parisudha merupakan tiga dasar perilaku yang harus disucikan, yaitu pikiran, perkataan dan perbuatan (Somawati, 2019). Adapun bagian dari Tri Kaya Parisudha yaitu manacika (berpikir yang baik), wacika (berkata yang baik), kayika (berbuat yang baik). Apabila ketiga dasar ini dikaitkan dengan pembelajaran kontekstual, maka akan mampu menciptakan generasi yang cerdas dan berkarakter.

Saat ini, orientasi pendidikan berada pada era revolusi industri 4.0 yang ditunjukkan oleh pesatnya perkembangan teknologi. Proses pembelajaran pada era ini diharapkan berjalan optimal sehingga dapat mengurangi dampak negatif perkembangan teknologi tersebut melalui pengembangan keterampilan pada pembelajaran abad 21 yakni $4 \mathrm{C}$ yang terdiri atas critical thinking, communication, collaboration, dan creativity. Pembelajaran abad 21 merupakan pembelajaran yang mengintegrasikan antara kecakapan pengetahuan, keterampilan, dan sikap, serta penguasaan terhadap TIK. Kecakapan tersebut dapat dikembangkan melalui berbagai model pembelajaran berbasis aktivitas yang sesuai dengan karakteristik kompetensi dan materi pembelajaran. Kecakapan yang dibutuhkan di abad 21 juga merupakan keterampilan berpikir tingkat tinggi (High Order Thinking Skill-HOTS) yang sangat diperlukan untuk mempersiapkan peserta didik dalam menghadapi tantangan global (Muzazanah, 2019).

Harapan pembelajaran abad 21 yang mengintegrasikan kecakapan pengetahuan, keterampilan, dan sikap, serta pengusaaan teknologi secara aplikatif masih belum berjalan dengan optimal. Terlebih, situasi pandemi Covid-19 telah merevolusi proses pendidikan sehingga pendidik harus cepat beradaptasi. Hal ini dikarenakan proses pembelajaran daring khususnya saat pandemi mengalami beberapa kendala seperti sinyal atau konektivitas, kuota internet, dan kondusivitas pelaksanaan pembelajaran yang masih lebih baik jika dilaksanakan dengan tatap muka (Winangun, 2020). Kendala ini menyebabkan, proses pembelajaran saat ini kembali terlaksana secara tekstual yang masih berada pada tatanan keterampilan berpikir tingkat rendah (Low Order Thinking Skils-LOTS) melalui kegiatan pembelajaran dan penugasan. Oleh karena itu, keterlibatan siswa dalam proses pembelajaran daring masih 
kurang maksimal seperti yang ditunjukkan Anugrahana (2020), 50\% siswa aktif secara penuh, $33 \%$ siswa terlibat aktif, dan $17 \%$ siswa kurang terlibat aktif dalam proses pembelajaran daring.

Kenyataan pelaksanaan pembelajaran ini memberikan tantangan dan peluang inovasi pembelajaran. Pada pihak guru, mindset pelaksanaan pembelajaran yang berorientasi pada keterampilan tingkat tinggi harus tetap diupayakan melalui penerapan pembelajaran inovatif salah satunya model Contextual and Teaching Learning Berbasis Tri Kaya Parisudha. Pada pihak siswa, proses pembelajaran yang dinamis dan dekat dengan keseharian siswa akan mampu mengembangkan keterampilan berpikir tingkat tinggi satunya model Contextual and Teaching Learning Berbasis Tri Kaya Parisudha.

Contextual Teaching and Learning (CTL) adalah pembelajaran yang mendorong kegiatan belajar dan pembelajaran berlangsung secara alamiah di dalam kelas sehingga siswa mengalami proses belajar bukan sekedar menstransfer pengetahuan (Rando, 2016; Dewi \& Primayana, 2019). Secara empiris dalam beberapa penelitian, model Contextual Teaching and Learning memiliki beberapa kelebihan dan memperoleh hasil sesuai harapan. Wirdaningsih, et al (2017) menunjukkan bahwa Contextual and Teaching Learning efektif untuk meningkatkan kemampuan pemecahan masalah matematik dan aktivitas siswa. Selanjutnya, desain pembelajaran tematik integratif berbasis pendekatan CTL memberikan capaian hasil belajar yang lebih tinggi dibandingkan desain pembelajaran tematik rancangan pemerintah (Saputri \& Mawardi, 2017). Penerapan model pembelajaran kontekstual dapat meningkatkan hasil belajar siswa pada materi gaya (Handini et al, 2016). Begitu pula, penerapan perangkat pembelajaran IPA terpadu berbasis CTL dapat mengembangkan sikap kepedulian terhadap lingkungan (Muhlisin, 2012).

Keunggulan secara empiris sesuai dengan penelitian di atas menjadi dasar penerapan model pembelajaran Contextual and Teaching Learning yang pada penelitian ini diintegrasikan dengan konsep Tri Kaya Parisudha. Konsep ini menekankan pada tiga dasar perilaku individu yang harus disucikan, yaitu pikiran, perkataan, dan perbuatan (Somawati \& Diantari, 2019). Integrasi ini diharapkan mampu mewujudkan pembelajaran yang sesuai dengan orientasi keterampilan abad 21 baik critical thinking, communication, collaboration, maupun creativity sehingga siswa mampu memperoleh capaian hasil belajar yang optimal baik pada kompetensi sikap, pengetahuan, dan keterampilannya.

Berdasarkan uraian di atas, maka dirasa penting untuk mengembangkan sebuah rencana pelaksanaan pembelajaran berorientasi pembelajaran abad 21 yang secara umum bertujuan untuk memberikan kiat kepada pendidik agar selalu mengupayakan proses pembelajaran yang optimal kepada siswa. Selanjutnya secara khusus, bertujuan untuk: (i) mengembangkan RPP Kurikulum 2013 berorientasi pembelajaran abad 21 dengan model contextual and teaching learning (CTL) berbasis Tri Kaya Parisudha; dan (ii) mengetahui validitas pengembangan RPP Kurikulum 2013 berorientasi pembelajaran abad 21 dengan model Contextual and Teaching Learning berbasis Tri Kaya Parisudha. Tujuan ini terangkum dalam suatu penelitian pengambangan yang berjudul "Pengembangan RPP Kurikulum 2013 Berorientasi Pembelajaran Abad 21 dengan Model Contextual and Teaching Learning Berbasis Tri Kaya Parisudha". 


\section{Metode Penelitian}

Jenis penelitian ini adalah penelitian pengembangan. Desain penelitian ini adalah penelitian pengembangan desain dan produk (Design and Development) dengan menggunakan Model ADDIE (Analysis, Design, Development, Implementation, Evaluation) (Kurt, 2017). Pada tahap analisis (analysis) dilakukan wawancara dengan guru SD kecamatan buleleng terkait permasalahan pembelajaran di sekolah. Pada tahap desain (design) dilakukan perancangan pengembangan produk. Pada tahap pengembangan (development) dilakukan pengembangan sintaks, pengembangan RPP sesuai sintaks, termasuk pengumpulan referensi. Pada tahap implementasi (implementation) dilakukan validasi kepada ahli bahasa dan ahli konten untuk mengetahui validitas atau kelayakan produk. Tahap evaluasi (evaluation) dilakukan uji coba terbatas kepada 6 orang mahasiswa PGSD dan 8 orang guru SD. Metode pengumpulan data yang dikumpulkan dalam penelitian ini adalah menggunakan kuesioner. Metode analisis deskriptif kuantitatif digunakan untuk mengklasifikasi hasil kuesioner dengan para ahli yaitu ahli bahasa dan ahli konten serta hasil respons mahasiswa PGSD dan guru SD. Untuk mengetahui kriteria kelayakannya, rata-rata skor hasil kuesioner yang diperoleh selanjutnya disesuaian dengan tabel pengkonfersian kategori PAIT (Penilaian Acuan Ideal Teoritik).

\section{Hasil dan Pembahasan}

Dalam pembelajaran Abad 21, telah dijelaskan keterampilan yang harus dikuasai oleh mahasiswa adalah keterampilan 4C yang terdiri dari critical thinking, collaboration, creativity, dan communication. Dari keempat keterampilan tersebut, mengasah kemampuan intelegensi dan emosional siswa. Namun, untuk menciptakan keseimbangan antara kecerdasan dan moral, diperlukan nilai-nilai yang bisa dijadikan pedoman bagi mahasiswa untuk dapat mengembangkan potensinya. Nilai yang dimaksud adalah Tri Kaya Parisudha. Tri Kaya Parisudha terdiri dari Manacika, Wacika, dan Kayika. Ketiga landasan ini perlu diterapkan dan dikaitkan dalam mengasah keterampilan 4C mahasiswa sehingga dapat mencetak calon guru yang cerdas dan berkarakter. Adapun kaitan antara keterampilan abad 21 dengan Tri Kaya Parisudha yaitu keterampilan berpikir kritis (critical thinking) dilandasi oleh pikiran yang baik (manacika), keterampilan berkomunikasi (communication) dilandasi oleh perkataan yang baik (wacika), keterampilan bekerjasama/ berkolaborasi (collaboration) serta keterampilan berkreasi (creativity) dilandasi oleh perbuatan baik (kayika). Komponen inilah yang selanjutnya dituangkan dalam sintaks model contextual and teaching learning. Berikut sintaks model contextual and teaching learning berorientasi pembelajaran abad 21 berbasis Tri Kaya Parisudha.

Tabel 1. Sintaks Model Contextual Teaching and Learning Berorientasi Pembelajaran Abad 21 Berbasis Tri Kaya Parisudha

\begin{tabular}{|c|c|c|}
\hline Tahap & Aktivitas Guru & Aktivitas Siswa \\
\hline $\begin{array}{l}\text { Konstruktivisme } \\
\text { Melaksanakan } \\
\text { kegiatan konstruksi } \\
\text { pengetahuan untuk } \\
\text { semua topik } \\
\text { (critical thinking, } \\
\text { Manacika) }\end{array}$ & $\begin{array}{l}\text { Guru menyajikan kejadian- } \\
\text { kejadian yang menimbulkan } \\
\text { konflik kognitif dan rasa ingin } \\
\text { tahu siswa }\end{array}$ & $\begin{array}{l}\text { Siswa mengamati kejadian-kejadian } \\
\text { atau permasalahan yang diberikan } \\
\text { guru yang menimbulkan rasa ingin } \\
\text { tahu }\end{array}$ \\
\hline
\end{tabular}




\author{
Inquiry \\ Menggunakan \\ keterampilan berpikir \\ kritis untuk \\ mengkritisi suatu \\ permasalahan yang \\ diberikan \\ (critical thinking, \\ Manacika)

\section{Quaestioning} \\ Mengembangkan rasa \\ ingin tahu dengan \\ mengajukan \\ pertanyaan \\ (communication, \\ Wacika)

\section{Learning Community} \\ Menciptakan \\ masyarakat belajar \\ (collaboration, Kayika)
}

\section{Modelling}

Menghadirkan model (critical thinking,

communication,

Manacika, Wacika)

\section{Reflection}

Melakukan refleksi

(communication,

Wacika)

Authentic assessment Melakukan penilaian yang sebenarnya (creativity, Kayika)
Guru memfasilitasi siswa untuk mengkritisi permasalahan serta mengaitkan permasalahan dengan materi yang diberikan

Guru memfasilitasi siswa untuk menanyakan materi yang belum dimengerti

Guru membimbing siswa untuk belajar kelompok dan bekerjasama dengan teman sekelompoknya dalam bertukar pengalaman dan berbagi ide.

Guru menampilkan contoh pembelajaran agar siswa dapat berfikir, bekerja, dan belajar

Guru menyimpulkan materi pembelajaran, menganalisis manfaat pembelajaran, dan penindak lanjutkan kegiatan pembelajaran

Guru mengukur kemampuan dan pengetahuan keterampilan siswa melalui penilaian produk dan tugas-tugas yang relevan dan kontekstual
Siswa menggunakan keterampilan berpikir kritis untuk mengkritisi permasalahan atau kejadian yang diberikan untuk mengaitkannya dengan materi serta menemukan solusi pemecahannya

Siswa menanyakan mengenai hal yang belum dipahami berkaitan dengan materi yang diberikan

Siswa secara berkelompok mendiskusikan permasalahan atau tugas yang diberikan berkaitan dengan permasalahan atau materi

Siswa memperhatikan model atau contoh yang diberikan guru agar siswa lebih paham dan pembelajaran lebih kontekstual

Siswa bersama guru menyimpulkan materi pembelajaran serta melaksanakan tindak lanjut yang diberikan guru

Siswa mengikuti penilaian yang diberikan guru baik untuk mengukur pengetahuan atau keterampilan

Sintaks tersebut yang selanjutnya dituangkan dalam sebuah RPP Kurikulum 2013. Berikut diberikan contoh pengembangan RPP Kurikuluum 2013 berorientasi pembelajaran abad 21 dengan model contextual and teaching learning Berbasis Tri kaya Parisudha.

\section{RENCANA PELAKSANAAN PEMBELAJARAN (Sesuai Edaran Nomor 14 Tahun 2019)}

$\begin{array}{ll}\text { Satuan Pendidikan } & : \text { SD .......... } \\ \text { Kelas / Semester } & : 4 / 1 \\ \text { Tema } & : 8 \text { (Daerah Tempat Tinggalku) } \\ \text { Sub Tema } & : 1 \text { (Lingkungan Tempat Tinggalku) }\end{array}$


Pembelajaran ke : 3

Alokasi waktu $\quad$ : 2x35 Menit

\section{A. TUJUAN PEMBELAJARAN}

1. Dengan kegiatan membaca teks tentang pengaruh lingkungan terhadap mata pencaharian penduduk, siswa mengetahui jenis pekerjaan penduduk berdasarkan tempat tinggalnya dengan cermat.

2. Dengan kegiatan mengamati keadaan alam lingkungan tempat tinggalnya, siswa dapat menjelaskan hubungan keadaan alam dengan mata pencaharian penduduk di lingkungan tempat tinggalnya dengan teliti.

3. Dengan kegiatan membaca teks cerita fiksi, siswa dapat menjelaskan pengertian dan peranan tokoh dengan jelas.

4. Dengan kegiatan membaca teks cerita fiksi, siswa dapat menjelaskan nilai pesan moral dalam cerita fiksi dengan benar.

5. Dengan mengamati ciri fisik anggota keluarga, siswa dapat menjelaskan karaktersitik individu dalam keluarga dengan baik.

\section{B. KEGIATAN PEMBELAJARAN}

Tabel 2 Kegiatan Pembelajaran

\begin{tabular}{|c|c|c|c|}
\hline Kegiatan & \multicolumn{2}{|r|}{ Deskripsi Kegiatan } & $\begin{array}{l}\text { Alokasi } \\
\text { Waktu }\end{array}$ \\
\hline Pendahuluan & $\begin{array}{l}\text { 1) } \\
\text { 2) } \\
\text { 3) }\end{array}$ & $\begin{array}{l}\text { Guru menyapa dan menanyakan kabar peserta didik. } \\
\text { Guru mengecek kehadiran peserta didik. } \\
\text { Guru mengajak siswa berdoa sebelum pembelajaran } \\
\text { dimulai. } \\
\text { Guru menyampaikan tujuan pembelajaran. }\end{array}$ & 15 menit \\
\hline \multicolumn{4}{|c|}{ Model Pembelajaran Kontekstual } \\
\hline \multirow{8}{*}{$\begin{array}{l}\text { Kegiatan } \\
\text { Inti }\end{array}$} & & Konstruktivisme (critical thinking, Manacika) & 140 menit \\
\hline & 1) & $\begin{array}{l}\text { Siswa membaca teks fiksi mengenai "dongeng ikan } \\
\text { mas". } \\
\text { Penemuan (Inquiry) (critical thinking, Manacika) }\end{array}$ & \\
\hline & 2) & $\begin{array}{l}\text { Siswa menemukan tokoh yang terdapat pada cerita ikan } \\
\text { mas kemudian mencari nilai pesan moral yang terdapat } \\
\text { dalam cerita. }\end{array}$ & \\
\hline & & Bertanya (Questioning) (communication, Wacika) & \\
\hline & 3) & $\begin{array}{l}\text { Siswa bertanya jawab mengenai nilai moral dan tokoh } \\
\text { yang terdapat dalam cerita ikan mas serta pekerjaan } \\
\text { yang terdapat dalam cerita tersebut. } \\
\text { Masyarakat Belajar (Learning Community) } \\
\text { (collaboration, Kayika) }\end{array}$ & \\
\hline & 4) & $\begin{array}{l}\text { Siswa secara berkelompok mengelompokkan jenis } \\
\text { pekerjaan lain berdasarkan lingkungan tempat } \\
\text { tinggalnya. }\end{array}$ & \\
\hline & 5) & $\begin{array}{l}\text { Siswa secara berkelompok membuat laporan } \\
\text { pengamatan sederhana sesuai kolom hasil pengamatan } \\
\text { di buku siswa tentang keadaan lingkungan dan mata } \\
\text { pencaharian penduduk di lingkungannya. } \\
\text { Pemodelan (Modelling) (critical thinking, communication, } \\
\text { Manacika, Wacika) }\end{array}$ & \\
\hline & 6) & $\begin{array}{l}\text { Siswa mengamati ciri fisik teman dalam kelompok serta } \\
\text { anggota keluarga masing-masing. }\end{array}$ & \\
\hline
\end{tabular}




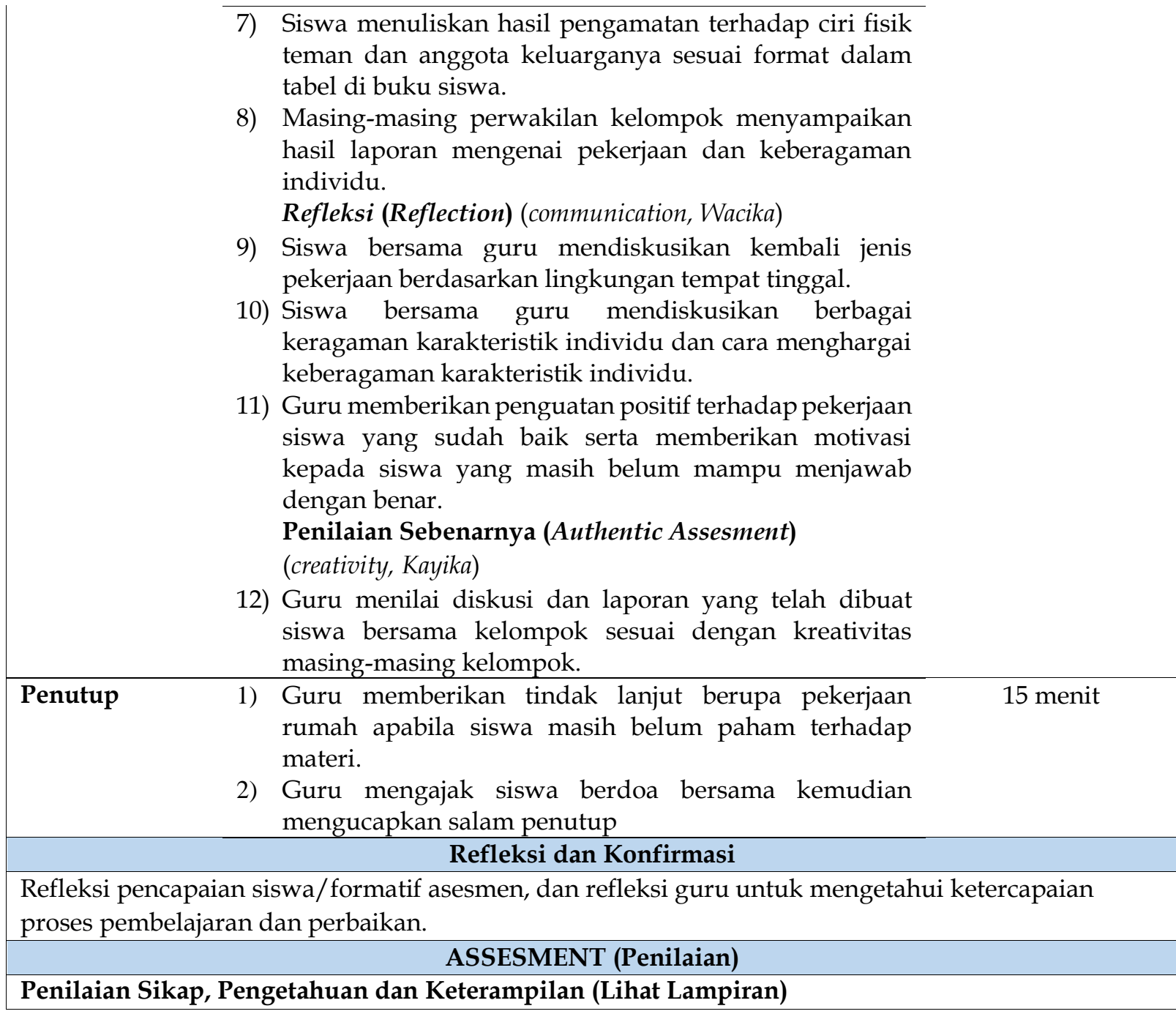

Mengetahui

Kepala Sekolah,
Guru Kelas 4 ,

NIP. 


\section{Hasil Uji Validitas Produk}

Setelah dilakukan pengembangan produk (development), tahap selanjutnya sesuai desain ADDIE yang diterapkan yaitu tahap impementasi (implementation) berupa uji validitas yang diberikan kepada ahli konten dan ahli bahasa untuk mengetahui kelayakan produk. Hasil uji validitas konten dan validitas bahasa dapat dilihat pada tabel berikut.

Tabel 3 Hasil Uji Validitas Konten Pengembangan

\begin{tabular}{cccc}
\hline No & Komponen & Mean & Kategori \\
\hline 1 & Legalitas & 3,40 & Sangat Baik \\
2 & Norma & 3,75 & Sangat Baik \\
3 & Materi/Substansi & 3,50 & Sangat Baik \\
& Rata-rata & 3,53 & Sangat Baik \\
\hline
\end{tabular}

Berdasarkan tabel 3, hasil uji validitas baik dari segi legalistas, norma, maupun materi/substansi memiliki kategori sangat baik, dengan rata-rata 3,53 yang juga berkategori sangat baik. Oleh karena itu pengembangan RPP kurikulum 2013 berorientasi pembelajaran abad 21 dengan model Contextual Teaching and Learning berbasis Tri Kaya Parisudha layak untuk diterapkan pada mahasiswa prodi PGSD.

Tabel 4 Hasil Uji Validitas Bahasa

\begin{tabular}{cccc}
\hline No & Komponen & Mean & Kategori \\
\hline 1 & Keterbacaan & 3,6 & Sangat Baik \\
2 & Kesesuaian dengan PUEBI & 3,4 & Sangat Baik \\
3 & Ketepatan dan kesesuaian pemilihan kata & 3,6 & Sangat Baik \\
& Rata-rata & 3,53 & Sangat Baik \\
\hline
\end{tabular}

Berdasarkan tabel 4, diperoleh hasil validitas bahasa baik dari komponen keterbacaan, kesesuaian dengan PUEBI, ataupun ketepatan dan kesesuaian pemilihan kata memiliki kategori sangat baik. Rata-rata hasil uji validitas ahli bahasa yaitu 3,53 yang berkategori sangat baik. Hal ini menunjukkan pengembangan RPP Kurikulum 2013 berorientasi pembelajaran abad 21 dengan model Contextual and Teaching Learning Berbasis Tri Kaya Parisudha layak dari segi tata bahasa.

\section{Hasil Uji Coba Terbatas}

Selain uji validitas, perlu juga mengetahui hasil uji coba terbatas untuk mengetahui respons dari mahasiswa PGSD dan guru SD terkait dengan pengembangan RPP Kurikulum 2013 berorientasi pembelajaran abad 21 dengan model Contextual and Teaching Learning Berbasis Tri Kaya Parisudha. Hasil respons tersebut dapat dilihat pada tabel berikut.

Tabel 5. Hasil Respons Mahasiswa PGSD

\begin{tabular}{cccc}
\hline No & Komponen & Mean & Kategori \\
\hline 1 & Inovasi & 3,50 & Sangat Baik \\
2 & Tata bahasa dan Sistematika Penulisan & 3.54 & Sangat Baik \\
3 & Kesesuaian Teori dengan Implementasi & 3.27 & Sangat Baik \\
4 & Kebermanfaatan & 3.37 & Sangat Baik \\
& Rata-rata & $\mathbf{3 , 5 0}$ & Sangat Baik \\
\hline
\end{tabular}

Berdasarkan tabel 5, diketahui bahwa hasil uji coba terbatas berdasarkan respons mahasiswa PGSD baik dari komponen inovasi, tata bahasa dan sistematika penulisan, kesesuaian teori dengan implementasi maupun kebermanfaatan memiliki kategori sangat baik. Rata-rata hasi uji coba terbatas yang diperoleh dari respons mahasiswa PGSD yaitu 3,50 dengan kategori sangat baik. Hal ini menunjukkan bahwa pengembangan RPP Kurikulum 
2013 dengan model Contextual and Teaching Learning berorientasi pembelajaran abad 21 berbasis Tri Kaya Parisudha layak untuk diterapkan dalam mengembangkan pembelajaran inovatif pada program studi pendidikan guru sekolah dasar.

Tabel 6. Hasil Respons Guru SD

\begin{tabular}{cccc}
\hline No & Komponen & Mean & Kategori \\
\hline 1 & Inovasi & 3.54 & Sangat Baik \\
2 & Bahasa dan Penulisan & 3,37 & Sangat Baik \\
3 & Kesesuaian Teori dengan Implementasi & 3.32 & Sangat Baik \\
4 & Kebermanfaatan & 3.42 & Sangat Baik \\
& Rata-rata & $\mathbf{3 , 3 7}$ & Sangat Baik \\
\hline
\end{tabular}

Berdasarkan tabel 6, diketahui bahwa hasil uji coba terbatas berdasarkan respons guru SD baik dari komponen inovasi, bahasa dan penulisan, kesesuaian teori dan implementasi maupun kebermanfaatan, memiliki kategori baik. Rata-rata hasil uji coba terbatas yang diperoleh dari respons guru SD yaitu 3,37 dengan kategori sangat baik. Berdasarkan hal tersebut, maka pengembangan RPP Kurikulum 2013 dengan model Contextual and Teaching Learning berorientasi pembelajaran abad 21 berbasis Tri Kaya Parisudha layak untuk diterapkan dalam mengembangkan pembelajaran inovatif pada program studi pendidikan guru sekolah dasar.

Berdasarkan kedua hasil uji validitas maupun hasil uji coba terbatas diperoleh hasil sangat baik. Hal ini menunjukkan pengembangan RPP Kurikulum 2013 dengan model Contextual and Teaching Learning berorientasi pembelajaran abad 21 berbasis Tri Kaya Parisudha layak untuk diterapkan pada program studi pendidikan guru sekolah dasar. Penerapan model Contextual and Teaching Learning mampu mengasah keterampilan abad 21 yaitu critical thinking, communication, collaboration, dan creativity.

Model Contextual and Teaching Learning berorientasi pembelajaran abad 21 dapat dikaitkan dengan dengan penanaman karakter melalui konsep kearifan lokal Tri Kaya Parisudha yaitu manacika, wacika, dan kayika. Model kontekstual merupakan konsep belajar yang beranggapan bahwa anak akan belajar lebih baik jika lingkungan diciptakan secara ilmiah, artinya belajar akan lebih bermakna jika anak "bekerja" dan "mengalami" sendiri apa yang dipelajarinya, bukan sekedar "mengetahuinya". Sesuai dengan pendapat Majid (2013) yang menyatakan bahwa pembelajaran kontekstual (Contextual Teaching and Learning) merupakan suatu proses pendidikan yang holistik dan bertujuan memotivasi siswa untuk memahami makna materi pelajaran yang dipelajarinya dengan mengaitkan materi tersebut terhadap konteks kehidupan mereka sehari-hari (konteks pribadi, sosial dan kultural) sehingga mahasiswa memiliki pengetahuan atau keterampilan yang secara fleksibel dapat diterapkan dari satu permasalahan ke permasalahan lainnya.

Proses pembelajaran yang dilaksanakan dengan dunia nyata anak akan memberikan beberapa kelebihan yang dapat diperolehnya, yaitu 1) pembelajaran menjadi lebih bermakna dan nyata; 2) pembelajaran lebih produktif dan mampu menumbuhkan penguatan konsep kepada siswa karena pembelajaran kontekstual menganut aliran konstruktivisme, dimana seorang siswa dituntun untuk menemukan pengetahuannya sendiri (Hosnan, 2014).

Model pembelajaran kontekstual terdiri atas beberapa komponen yaitu konstruktivisme, penemuan (inquiry), bertanya (questioning), masyarakat belajar (Learning community), pemodelan (modelling), refleksi (reflection), penilaian autentik (authentic assessment). Apabila dikaitkan dengan pembelajaran abad 21, maka komponen konstruktivisme dan penemuan 
berkaitan dengan critical thinking dalam keterampilan 4C yang harus dikuasai dalam pembelajaran abad 21 dan Manacika pada bagian Tri Kaya Parisudha. Hal ini dikarenakan dalam kegiatan mengkonstruksi pengetahuan maupun menemukan suatu konsep baru dibutuhkan pemikiran yang kritis. Oleh karena itu, apabila pembelajaran dilakukan secara kontekstual, maka kemampuan berpikir kritis (critical thinking) siswa akan terasah dan mengarah pada Manacika (berpikir yang baik). Dalam pandangan konstruktivisme bahwa pelajar tidak hanya menerima materi pelajaran berdasarkan apa kata pengajar, tetapi mereka mengkonstruksi materi pelajaran dari waktu ke waktu dalam benaknya. Dalam pandangan ini, siswa membangun dan menciptakan pengetahuan dengan cara mencoba memberi arti pada pengetahuannya sesuai dengan pengalamannya (Hasruddin, 2009).

Komponen selanjutnya yaitu bertanya (questioning). Pada kegiatan bertanya, guru mendorong, membimbing, dan menilai kemampuan berpikir siswa. Hal ini berkaitan dengan kemampuan berpikir kritis (critical thinking) dan kemampuan berkomunikasi (communication) dalam pembelajaran Abad 21. Ketika siswa bertanya maka ia perlu mengkritisi suatu permasalahan terlebih dahulu, sebelum mengajukan pertanyaan. Setelah itu, pertanyaan diajukan dengan santun dan bahasa yang interaktif sehingga melatih kemampuan komunikasi siswa. Pada konsep Tri Kaya Parisudha, kegiatan ini berkaitan dengan Manacika (berpikir yang baik) dan Wacika (berkata yang baik).

Pada komponen masyarakat belajar (learning community), pembelajaran kontekstual dilaksanakan dengan upaya kerjasama siswa untuk bertukar pengalaman atau berbagi ide serta mendiskusikan suatu permasalahan secara bersama-sama. Apabila dikaitkan dengan pembelajaran abad 21, kegiatan ini dapat mengasah kemampuan berkomunikasi (communication) dan pada konsep Tri Kaya Parisudha kegiatan ini berkaitan dengan Wacika (berkata yang baik). Pembiasaan untuk saling bekerjasama dalam sebuah kelompok, dapat mewujudkan kebiasaan siswa untuk berkomunikasi dengan baik. Hal ini sesuai dengan hasil penelitian Aswida (2012) yang menyatakan bahwa bimbingan kelompok bertujuan menghilangkan ketegangan-ketegangan emosi yang dialami siswa, salah satu nya kecemasan saat berkomunikasi.

Komponen selanjutnya yaitu pemodelan (modelling). Pada komponen ini siswa mempelajari sesuatu melalui model atau subjek/objek sebagai contoh. Misalnya siswa belajar mengenai proses gunung meletus, maka guru mencontohkan siswa membuat percobaan peristiwa gunung meletus menggunakan bahan seperti soda, dan lain sebagainya yang berupa tiruan dari peristiwa sebenarnya. Kemudian siswa secara berkelompok mencoba menirukan langkah-langkah yang dicontohkan oleh guru. Pada saat siswa melihat langsung suatu objek atau subjek pembelajaran, maka pembelajaran siswa menemukan kebermaknaan dalam belajar sehingga pengetahuan yang ditemukan akan tersimpan dalam memori jangka panjang. Apabila dikaitkan dengan pembelajaran Abad 21, maka kegiatan ini berkaitan dengan kemampuan berkolaborasi (collaboration) dan pada konsep Tri Kaya Parisudha kegiatan ini berkaitan dengan Kayika (berperilaku yang baik). Artinya suatu permasalahan akan dapat dipecahkan dalam kelompok apabila sesama anggota kelompok menunjukkan perilaku baik selama berkolaborasi atau bekerjasama.

Komponen selanjutnya yaitu refleksi. Pada komponen ini siswa merenungkan kembali pengetahuan yang diterima, mencatat apa yang telah dipelajari, membuat jurnal atau pun karya seni. Pembuatan jurnal atau karya seni sebagai suatu bentuk kreativitas siswa untuk 
menyimpan pengetahuan tersebut dalam struktur kognitifnya. Pada pembelajaran abad 21, kegiatan ini termasuk dalam kemampuan berkreativitas (creativity) dan berkaitan dengan Kayika (berbuat yang baik) pada Tri Kaya Parisudha. Perbuatan baik ini berarti siswa memiliki niat yang baik untuk melakukan suatu tindakan yang memberikan dampak positif bagi dirinya seperti pembuatan jurnal atau karya seni sebagai bentuk kreativitas (creativity) dalam mempelajari sesuatu.

Komponen terakhir yaitu penilaian yang sebenarnya (authentic assessment). Pada komponen ini siswa dinilai mengenai pengetahuan serta keterampilannya. Penilaian juga bisa dilihat dari tugas-tugas siswa yang relevan dan kontekstual. Pada pembelajaran abad 21, hal ini berkaitan dengan kemampuan berkreasi atau kreativitas siswa (creativity). Siswa dilatih untuk mengerjakan segala tugas dengan kreativitas yang dimilikinya sehingga tugas yang diberikan akan berguna bagi siswa tersebut terutama dalam penerapannya dalam kehidupan nyata. Pada konsep Tri Kaya Parisudha, kegiatan ini berkaitan dengan Kayika (berbuat baik). Artinya siswa dapat melakasanakan kewajibannya (swadharma) menjadi seorang siswa dalam menyelesaikan segala tugas yang diberikan baik untuk mengasah pengetahuan maupun keterampilannya.

Keberhasilan pengembangan ini juga didukung oleh hasil penelitian Rahmi dan Suparman (2019) yang berjudul "Analisis Kebutuhan Modul Dengan Pendekatan CTL untuk Meningkatkan Motivasi Belajar dan Keterampilan 4C pada Peserta Didik". Hasil penelitiainnya menunjukkan bahwa pertama, guru memerlukan modul yang sesuai dengan model pembelajaran dan yang memuat penanaman motivasi belajar dan keterampilan 4C. Kedua, guru memerlukan bahan ajar yang sesuai dengan karakteristik peserta didik. Ketiga, CTL merupakan salah satu pendekatan pembelajaran yang dapat diterapkan untuk meningkatkan motivasi belajar dan keterampilan 4C.

Selain itu, penelitian yang dilakukan Suarjana, et al (2018) yang berjudul "Pengaruh Model Pembelajaran CTL Berorientasi Tri Kaya Parisudha terhadap Hasil Belajar Matematika". Hasil penelitiannya menunjukkan bahwa terdapat perbedaan yang signifikan hasil belajar matematika antara kelompok siswa yang dibelajarkan menggunakan model pembelajaran CTL berorientasi Tri kaya Parisudha dan kelompok siswa yang tidak dibelajarkan menggunakan model pembelajaran CTL berorientasi Tri kaya Parisudha. Jika dikaitkan dengan pengembangan penelitian ini, maka pengembangan RPP Kurikulum 2013 dengan model Contextual and Teaching Learning berbasis Tri Kaya Parisudha dapat mengembangkan keterampilan berpikir kritis, berkomunikasi, bekerjasama, ataupun berkreasi sesuai dengan keterampilan abad 21 yang perlu dikembangkan.

Berdasarkan pembahasan teori tentang model Contextual and Teaching Learning yang erat kaitannya dengan keterampilan abad 21 dan konsep kearifan lokal Tri Kaya Parisudha serta beberapa hasil penelitian yang telah dilaksanakan sebelumnya, maka secara teoritis dan empiris pengembangan RPP kurikulum 2013 berorientasi pembelajaran abad 21 dengan model Contextual and Teaching Learning berbasis Tri Kaya Parisudha sangat layak dan baik untuk dimplementasikan. Hal ini dikarenakan pembelajaran yang dilaksanakan secara kontekstual akan mewujudkan pembelajaran bermakna sehingga mampu mengembangkan keterampilan abad 21. Apalagi, proses pembelajaran ini dilaksanakan berbasis kearifan lokal Tri Kaya Parisudha yang mampu menjadi pijakan pendidikan karakter untuk mendukung keterampilan 
abad 21. Jadi, proses pembelajaran yang dilaksanakan akan memberikan capaian pembelajaran pada aspek sikap, pengetahuan, dan keterampilan yang optimal.

\section{Kesimpulan}

Berdasarkan pembahasan di atas, maka dapat disimpulkan bahwa pengembangan RPP kurikulum 2013 berorientasi pembelajaran abad 21 dengan model Contextual and Teaching Learning berbasis Tri Kaya Parisudha telah dilakukan dengan mengembangkan sintaksnya terlebih dahulu, kemudian diimplementasikan dalam RPP kurikulum 2013 sesuai SE Mendikbud nomor 14 Tahun 2019. Berdasarkan hasil uji validitas dan uji coba terbatas, diperoleh hasil valid dengan kategori sangat baik. Hal ini menunjukkan bahwa pengembangan RPP kurikulum 2013 berorientasi pembelajaran abad 21 dengan model Contextual and Teaching Learning berbasis Tri Kaya Parisudha layak untuk diterapkan pada Program Studi Pendidikan Guru Sekolah Dasar

\section{Daftar Pustaka}

Anugrahana, A. (2020). Hambatan, Solusi dan Harapan: Pembelajaran Daring Selama Masa Pandemi Covid-19 oleh Guru Sekolah Dasar. Scholaria: Jurnal Pendidikan dan Kebudayaan. 10(3), (282-289).

Aswida, W., Marjohan, dan Y. Syukur. 2012. Efektifitas Layanan Bimbingan Kelompok dalam Mengurangi Kecemasan Berkomunikasi pada Siswa. Konselor : Jurnal Ilmiah Konseling. 1(1), (1-11).

Dewi, P. Y. A. \& Primayana. K. H. (2019). Effect of Learning Module with Setting Contextual Teaching and Learning to Increase the Understanding of Concepts. International Journal of Education and Learning. 1(1), (19-26).

Handini, D., Gusrayani, D., Panjaitan, R. L. Penerapan Model Contextual Teaching and Learning meningkatkan Hasil Belajar Siswa Kelas IV pada Materi Gaya. Jurnal Pena Imiah: 1(1), (451-460).

Hasruddin. (2009). Memaksimalkan Kemampuan Berpikir Kritis Melalui Pendekatan Kontekstual. Jurnal Tabularasa PPS UNIMED. 6(1), (48-60).

Hosnan, M. (2014). Pendekatan Saintifik dan Kontekstual dalam Pembelajaran Abad 21. Bogor: Ghalia Indonesia.

Kurt, S. (2017). "ADDIE Model: Instructional Design," Educatonal Technology Online, https://educationaltechnology.net/the-addie-model-instructional-design/ (diakses 12 Februari 2021).

Majid, Abdul. (2013). Strategi Pembelajaran. Bandung: PT. Remaja Rosdakarya.

Muhlisin, A. (2012). Pengembangan Perangkat Pembelajarab IPA Terpadu Berbasis Contextual Teaching and Learning (CTL) dengan Model Pembelajaran Kooperatif STAD Tema Polusi Udara. Jpournal of Educational Research and Evaluation. 1(2), (139-145).

Muzazanah. (2019). Implementasi Pembelajaran Berdasarkan Standar Proses dan Pembelajaran Abad 21. BDK Jakarta Kementerian Agama RI. Tersedia pada https://bdkjakarta.kemenag.go.id/berita/implementasi-pembelajaran-berdasarkanstandar-proses-dan-pembelajaran-abad-21. Diakses pada 12 Februari 2021.

Rahmi, A. dan Suparman. (2019). Analisis Kebutuhan Modul dengan Pendekatan CTL untuk Meningkatkan Motivasi Belajar dan Keterampilan 4C pada Peserta Didik. Prosiding Sendika. 5(1), (121-126). 
Rando, A. R. (2016). Pengembangan Perangkat Pembelajaran dalam Implementasi Strategi Contextual Teaching Learning untuk Meningkatkan Hasil Belajar IPS Pokok Bahasan Perkembangan Teknologi. Jurnal Pendidikan. 1(1), (1-11)

Rusman. (2013). Model-model Pembelajaran : Mengembangkan Profesionalisme Guru. Jakarta: PT. Raja Grafindo Persada.

Saputri, A. T. W. \& Mawardi. (2017). Pengembangan Desain pembelajaran Tematik Integratif Berbasis Pendekatan Contextual Teaching and Learning (CTL) Kelas 4 Sekolah Dasar. Jurnal Ilmiah "Pendidikan Dasar". 4(2), (104-114).

Somawati, A.V. dan N.M.Y.A. Diantari. (2019). Implementasi Ajaran Tri Kaya Parisudha dalam Membangun Karakter Generas Muda Hindu di Era Digital. Jurnal Pasupati. 6(1).

Winangun, I M. A. (2020). Perspektif Mahasiswa terhadap Pengelolaan Pembelajaran Online Dimasa Pandemi Covid-19. Widyalaya: Jurnal Ilmu Pendidikan. 1(1), (19-27). 